\title{
Tregs and allergic disease
}

\author{
Douglas S. Robinson, ${ }^{1,2}$ Mark Larché, ${ }^{1}$ and Stephen R. Durham¹
}

${ }^{1}$ Department of Allergy and Clinical Immunology, National Heart and Lung Institute, and ${ }^{2}$ Section of Leukocyte Biology,

Biomedical Sciences Division, Faculty of Medicine, Imperial College London, London, United Kingdom.

\begin{abstract}
Allergic diseases such as asthma, rhinitis, and eczema are increasing in prevalence and affect up to $15 \%$ of populations in Westernized countries. The description of Tregs as $T$ cells that prevent development of autoimmune disease led to considerable interest in whether these Tregs were also normally involved in prevention of sensitization to allergens and whether it might be possible to manipulate Tregs for the therapy of allergic disease. Current data suggest that $\mathrm{Th} 2$ responses to allergens are normally suppressed by both $\mathrm{CD} 4^{+} \mathrm{CD} 25^{+}$Tregs and IL-10 Tregs. Furthermore, suppression by these subsets is decreased in allergic individuals. In animal models, Tregs could be induced by high- or low-dose inhaled antigen, and prior induction of such Tregs prevented subsequent development of allergen sensitization and airway inflammation in inhaled challenge models. For many years, allergen-injection immunotherapy has been used for the therapy of allergic disease, and this treatment may induce IL-10 Tregs, leading to both suppression of Th2 responses and a switch from IgE to IgG4 antibody production. Improvements in allergen immunotherapy, such as peptide therapy, and greater understanding of the biology of Tregs hold great promise for the treatment and prevention of allergic disease.
\end{abstract}

\section{Allergic disease}

Atopic allergic sensitization is defined by production of IgE against environmental antigens such as house dust mites, grass pollen, and animal proteins and can lead to diseases that include asthma, rhinitis and atopic dermatitis (1). These disorders affect $10-15 \%$ of Western populations, and their prevalence has doubled in the last $10-15$ years. Triggering an immune response through allergen-specific IgE on the surface of mast cells and basophils can lead to immediate symptoms through release of histamine and other mediators while eosinophilic airway inflammation contributes to airway hyperresponsiveness (AHR) in asthma (1). Switching of B cells to IgE production and accumulation of eosinophils are under the control of Th2 lymphocytes through production of IL-4 and IL-5. These cells also produce IL-9 and IL-13, which contribute to AHR in asthma $(2,3)$.

Regulatory or suppressive $\mathrm{T}$ cells have increasingly been defined as important in the prevention of autoimmune disease and other immunopathologies (4); the biology and mechanism of suppression by these cells is reviewed elsewhere in this series. Whether Tregs normally also prevent atopic sensitization and how this regulatory process becomes defective or is bypassed in those individuals who develop allergic disease are areas of much current research. Additionally, the potential for manipulation of Tregs for therapy is clearly attractive for many disease types. Allergen-injection immunotherapy has been used for control of allergic disease for many years and appears to act through modulation of the Th2 response to the allergen, either by immune deviation of allergen-specific Th2 responses in favor of Th1 responses and/or through the induction of Tregs. Understanding the mechanism of therapeutic benefit in this treatment may hold important lessons for immunoregulation in other diseases.

Interest in active $T$ cell suppression as a mechanism for immunological tolerance was reawakened by the demonstration by

Nonstandard abbreviations used: AHR, airway hyperresponsiveness; LAR, late asthmatic reaction; $\mathrm{PLA}_{2}$, phospholipase $\mathrm{A}_{2}$; TLR, toll-like receptor.

Conflict of interest: D.S. Robinson is a consultant to Lorantis Ltd. S.R. Durham is a consultant to ALK Abello and has received honoraria and research funding from ALK Abello, a manufacturer of allergy vaccines.

Citation for this article: J. Clin. Invest. 114:1389-1397 (2004).

doi:10.1172/JCI200423595.
Sakaguchi and others that neonatal thymectomy of mice leads to organ-specific autoimmune pathology that can be prevented by transfer of $\mathrm{CD}^{+} \mathrm{CD} 25^{+} \mathrm{T}$ cells from nonirradiated animals $(5,6)$. Shevach and coworkers developed an in vitro system, which has been used widely, showing that mouse $\mathrm{CD} 4^{+} \mathrm{CD} 25^{+}$ $\mathrm{T}$ cells do not proliferate in response to either anti-CD3 or antigenic stimulation and, furthermore, can inhibit the proliferative responses of $\mathrm{CD} 4^{+} \mathrm{CD} 25^{-} \mathrm{T}$ cells (7). Use of this in vitro assay for the study of $\mathrm{T}$ cell regulation allowed demonstration of suppression by human peripheral blood and thymic $\mathrm{CD} 4^{+} \mathrm{CD} 25^{+} \mathrm{T}$ cells (8-13). Thymus-derived $\mathrm{CD} 4^{+} \mathrm{CD} 25^{+}$regulatory cells have been termed naturally occurring Tregs. A number of other regulatory subsets have been described (see Table 1). These are largely $\mathrm{T}$ cell populations induced by in vitro or in vivo manipulation and have been termed adaptive Tregs (14), but it is of note that several reports also suggest the existence of naturally occurring Tregs within the $\mathrm{CD} 4^{+} \mathrm{CD} 25^{-} \mathrm{T}$ cell population (15). Currently there is intense interest in the interrelationship of naturally occurring and induced/adaptive $\mathrm{CD} 4^{+} \mathrm{CD} 25^{+} \mathrm{T}$ cells, IL-10-producing Tregs, and other regulatory subsets, such as Th3 cells described as occurring after induction of oral tolerance (16). It will be important to determine whether these cell types are distinct and how data from mouse models can be related to the development or treatment of human disease.

The mechanism of suppression by different Treg subsets remains controversial; different in vivo and in vitro studies raise possible roles for the immunosuppressive cytokines IL-10 and TGF- $\beta$ (including a membrane-bound form), the negative costimulatory molecules CTLA4 and PD-1, and the glucocorticoid-induced TNF receptor (6-12, 17-25). However, in vitro suppression by both mouse and human $\mathrm{CD} 4^{+} \mathrm{CD} 25^{+} \mathrm{T}$ cells can be detected in the absence or blockade of these pathways. An important advance in the understanding of the biology of regulation by $\mathrm{CD} 4^{+} \mathrm{CD} 25^{+}$ $\mathrm{T}$ cells occurred in the demonstration of the dependence of their suppressive phenotype on expression of the transcription factor Foxp3. Gene deletion of Foxp3 abrogated suppression by $\mathrm{CD} 4^{+} \mathrm{CD} 25^{+} \mathrm{T}$ cells whereas ectopic gene expression in $\mathrm{CD} 25^{-} \mathrm{T}$ cells rendered these cells suppressive (26-28). In addition, acquisition of regulatory phenotype by $\mathrm{CD} 4^{+} \mathrm{CD} 25^{-} \mathrm{T}$ cells, either 


\begin{tabular}{|c|c|c|}
\hline Type of Treg & Mechanism of suppression & Allergy active in (refs.) \\
\hline $\begin{array}{l}\mathrm{CD} 4+\mathrm{CD} 25^{+} \text {(naturally occurring, } \\
\text { i.e., thymically derived) }\end{array}$ & $\begin{array}{l}\text { Foxp3 contact dependent, } \\
\text { IL-10, TGF- } \beta, \text { CTLA4, PD-1A }\end{array}$ & $\begin{array}{c}\text { Mouse (41) } \\
\text { Human (52-55) }\end{array}$ \\
\hline $\mathrm{CD} 4+\mathrm{CD} 25^{+}$(induced) & IL-10, TGF- $\beta$ & $\begin{array}{l}\text { Mouse }(29,44) \\
\text { Human }(52-54)\end{array}$ \\
\hline Tr1 & IL-10, TGF- $\beta$ & Mouse (45) \\
\hline IL-10 Treg & Contact dependent, IL-10 (in vivo) & $\begin{array}{l}\text { Mouse (46-48) } \\
\text { Human (55) }\end{array}$ \\
\hline Th1 cells & IFN- $\gamma$, IL-10 & Mouse (33) \\
\hline
\end{tabular}

It remains unclear how these subtypes are interrelated and whether human $C D 4+C D 25^{+} T$ cells represent naturally occurring or adaptive Tregs (see ref. 14). Which subtypes are induced (if any) by whole allergen immunotherapy or peptide immunotherapy also remains to be determined. AIL-10, TGF- $\beta$, CTLA4, and PD-1 are implicated in suppression by naturally occurring CD4+CD25+ T cells in some, but not all, reports.

in another report (40). In a doubletransgenic model, $\mathrm{CD} 4^{+} \mathrm{CD} 25^{+}$OVAspecific TCR transgenic T cells infiltrated the lungs of animals expressing the OVA antigen under a lung-specific promoter. Although these cells suppressed airway inflammation, they did not prevent AHR in response to inhaled OVA (41). These data suggest that, at least in animal models, naturally occurring $\mathrm{CD} 4^{+} \mathrm{CD} 25^{+} \mathrm{T}$ cells which develop during normal thymic maturation may not be sufficient to prevent allergic airway disease. In other models, $\mathrm{CD} 4^{+} \mathrm{CD} 25^{+}$Tregs have been induced from $\mathrm{CD} 4^{+} \mathrm{CD} 25^{-} \mathrm{T}$ cells. In one report, these adaptive $\mathrm{CD} 4{ }^{+} \mathrm{CD} 25^{+} \mathrm{T}$ cells were derived after antigen exposure in the presence of

through the action of TGF- $\beta$ or coculture with $\mathrm{CD} 4^{+} \mathrm{CD} 25^{+}$Tregs, was associated with acquisition of Foxp3 expression (29). Mutation of Foxp3 was described in patients with immune dysregulation, polyendocrinopathy, enteropathy, and X-linked syndrome (IPEX syndrome), a syndrome which includes the development of atopic dermatitis; thus Foxp3 Tregs may be involved in the prevention of allergic sensitization (30). It has been suggested that Foxp3 acts as a master switch for the regulatory phenotype in much the same way as do GATA3 and T-bet in Th2 and Th1 T cell phenotypes respectively (31). However, it is of note that IL-10-producing Tregs do not show overexpression of Foxp3, which suggests that regulation can occur through different pathways (32).

In addition, Th1 cells have inhibitory effects on Th2 function (partially through production of the immunomodulatory cytokine IL-10) and have been shown to prevent or diminish airway inflammation in at least some mouse allergen challenge models (33). This was also shown by in vitro overexpression of the Th1-associated transcription factor T-bet, which was reported to reduce expression of GATA 3 and Th2 cytokines in Th2 cells and is underexpressed in the airway in asthmatics compared to control subjects $(34,35)$. Thus in the context of allergic disease, Th1 cells may be suppressive, and immune deviation from a Th2 to a Th1 response may be a legitimate regulatory strategy for treatment of allergic disease. In addition, NK T cells and TCR $\gamma \delta$-bearing cells have also been suggested as having regulatory roles (36).

\section{Tregs in mouse models of allergic disease}

A number of reports of experiments using mouse models have suggested a potential role for Tregs in the prevention and control of Th2-mediated pathology.

Mouse $\mathrm{CD} 4^{+} \mathrm{CD} 25^{+} \mathrm{T}$ cells were shown to suppress the in vitro differentiation of Th 2 cells from naive $\mathrm{CD}^{+} \mathrm{T}$ cells but required preactivation to inhibit cytokine production from differentiated Th2 cells (37). In transgenic mice with monoclonal populations of $\mathrm{T}$ and $\mathrm{B}$ cells, a single immunization of antigen resulted in very high serum IgE levels, which could be prevented by both $\mathrm{CD} 25^{+}$and $\mathrm{CD} 4^{+} \mathrm{CD} 25^{-} \mathrm{T}$ cells. This suggested that Tregs normally prevent IgE responses (38). However, depletion of $\mathrm{CD} 4^{+} \mathrm{CD} 25^{+} \mathrm{T}$ cells actually reduced airway inflammation in a murine model of allergic sensitization (39), and transfer of $\mathrm{CD}^{+} \mathrm{CD} 25^{+} \mathrm{T}$ cells had no effect on inflammation or AHR
TGF- $\beta$ and expressed the transcription factor Foxp3. These cells could prevent house dust mite-induced airway inflammation in an inhaled allergen challenge model, although no data was presented on AHR (29). Repeated low-dose inhaled exposure to antigen induced tolerance to subsequent Th2 sensitization and airway pathology in mouse models $(42,43)$. Recently this was shown to depend on the induction of Foxp $3^{+} \mathrm{CD} 4^{+} \mathrm{T}$ cells that expressed surface TGF- $\beta$ and suppressed development of airway inflammation in vivo, and antigen-induced $\mathrm{T}$ cell proliferation in vivo, through a contact-dependent mechanism (44). In human peripheral blood one might expect that the $\mathrm{CD} 4^{+} \mathrm{CD} 25^{+} \mathrm{T}$ cell population will contain both naturally occurring and adaptive Tregs, and it will be of interest to determine how such subsets develop upon natural allergen exposure (see below).

In addition to the roles for $\mathrm{CD} 4^{+} \mathrm{CD} 25^{+} \mathrm{T}$ cells, the use of mouse models suggests potential roles for IL-10-producing Tregs in the suppression of allergic pathology. These include $\operatorname{Tr} 1$ clones derived by antigen stimulation in the presence of IL-10, which could prevent Th2 sensitization and IgE production if adoptively transferred prior to sensitization (45). Tolerance to inhaled antigen challenge can also be induced by high-dose intranasal antigen delivery to the respiratory tract in mice. This tolerance was shown to be dependent on IL-10 production by mature dendritic cells, which in turn induced development of IL-10-producing regulatory $\mathrm{CD}^{+} \mathrm{T}$ cells $(46,47)$. In addition, prior exposure to heat-killed Mycobacterium vaccae reduced both Th2 airway inflammation and AHR to subsequent allergen challenge, and this was mediated by $\mathrm{CD}^{+} \mathrm{CD} 45 \mathrm{RB}^{\text {lo }} \mathrm{T}$ cells acting through both IL-10 and TGF- $\beta$ (48). IL-10-producing Tregs have also been derived by antigen stimulation of either mouse or human naive $\mathrm{CD}^{+} \mathrm{T}$ cells in the presence of immunosuppressive drugs, dexamethasone, and vitamin D3 (49), although these have not been tested in mouse models of allergic disease. A further possible means of inducing regulation was demonstrated by Hoyne and colleagues. House dust mite-pulsed antigen-presenting cells that had been engineered to overexpress the Notch ligand Jagged-1 were injected into mice and shown to induce $\mathrm{CD} 4^{+} \mathrm{T}$ cells that could prevent house dust mite-induced airway pathology in an allergen challenge model (50). The Notch signaling system is involved in cell fate decision (including in the immune system) and may influence whether a proinflammatory or anti-inflammatory response is mounted. 


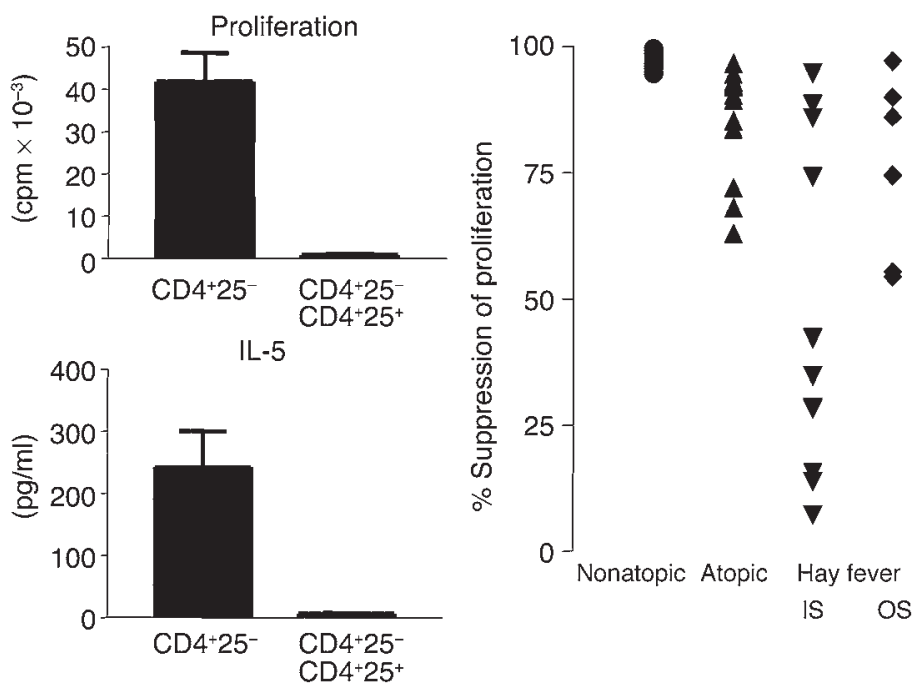

Figure 1

Peripheral blood $\mathrm{CD} 4{ }^{+} \mathrm{CD} 25^{+} \mathrm{T}$ cells from atopic volunteers show reduced suppressive ability in allergen-stimulated $T$ cell cultures. CD4 ${ }^{+} C D 25^{-} T$ cells were separated from peripheral blood by immunomagnetic separation, then cultured with allergen extracts either alone or mixed with $\mathrm{CD} 4{ }^{+} \mathrm{CD} 25^{+} \mathrm{T}$ cells. Proliferation was assessed by incorporation of tritiated thymidine (shown as $\mathrm{cpm}$ ), and IL-5 was measured in supernatants at day 6 of cultures by Luminex bead array. Data shown are means and standard errors for cpm and IL-5 from 9 separate nonatopic donors, showing almost complete suppression of responses of $C D 44^{+} C D 25^{-} T$ cells when $C D 4{ }^{+} C D 25^{+} T$ cells were added. When these data were expressed as percentage suppression (reduction in counts in the mixed culture compared with those in $\mathrm{CD} 4{ }^{+} \mathrm{CD} 25^{-} \mathrm{T}$ cells alone), suppression was significantly less when cells were obtained from atopic donors or volunteers with hay fever studied in or out of season (IS or OS). Suppression out of season was significantly more than that seen in season but still significantly less than in nonatopic controls. Figure adapted from Lancet (54), with permission from Elsevier.

Thus murine models of allergic disease demonstrate that Tregs have potential in preventing allergic sensitization and that such cells can be induced in vivo. However, which regulatory pathways act in allergic disease and how these cells suppress Th2 responses clearly remains controversial.

\section{Tregs and allergic responses in humans}

There have been few reports of activity of human Tregs on Th2 cells in vitro. Human thymocyte Th2 clones were relatively resistant to suppression of allergen-induced activation by autologous $\mathrm{CD} 4{ }^{+} \mathrm{CD} 25^{+}$thymocytes (51). However, human peripheral blood $\mathrm{CD} 4{ }^{+} \mathrm{CD} 25^{+} \mathrm{T}$ cells suppressed proliferation and Th2-type cytokine production by $\mathrm{CD} 4^{+} \mathrm{CD} 25^{-} \mathrm{T}$ cells stimulated in vitro with allergen $(52,53)$. Thus Tregs may act to prevent inappropriate $\mathrm{Th} 2$ responses to environmental allergens. One possible reason for development of atopic sensitization would therefore be a deficiency or failure of such regulation. Although initial reports found no clear difference in the suppressive ability of $\mathrm{CD} 4{ }^{+} \mathrm{CD} 25^{+} \mathrm{T}$ cells between atopic allergic and nonatopic control subjects $(52,53)$, a more recent study showed that the suppressive ability of $\mathrm{CD} 4^{+} \mathrm{CD} 25^{+} \mathrm{T}$ cells from atopic subjects in cocultures with allergen-stimulated autologous $\mathrm{CD} 4^{+} \mathrm{CD} 25^{-} \mathrm{T}$ cells was significantly less than that seen for cells from nonatopics (54) (Figure 1). There was no difference between atopic and nonatopic donors in the ability of their $\mathrm{CD} 4^{+} \mathrm{CD} 25^{+} \mathrm{T}$ cells to suppress $\mathrm{CD} 4^{+} \mathrm{CD} 25^{-}$ $\mathrm{T}$ cells activated via anti-CD3 and anti-CD28 monoclonal antibodies, suggesting that atopy is not associated with a generalized defect in regulatory capacity of $\mathrm{CD} 4^{+} \mathrm{CD} 25^{+} \mathrm{T}$ cells (54). One possibility was that the $\mathrm{CD} 4^{+} \mathrm{CD} 25^{+} \mathrm{T}$ cells isolated from the atopic subjects contained fewer Tregs and more activated effector T cells, since CD25 is also expressed by recently activated or memory effector $\mathrm{T}$ cells. However, no differences in other phenotypic markers were detected to suggest an excess of activated $\mathrm{T}$ cells, and differences in $\mathrm{CD} 4^{+} \mathrm{CD} 25^{+} \mathrm{T}$ cell suppression of grass pollen-stimulated cultures between patients with hay fever and nonatopic controls persisted even outside the pollen season (Figure 1). Human $\mathrm{CD}^{+} \mathrm{CD} 25^{+} \mathrm{T}$ cells were confirmed to express mRNA for the Foxp3 transcription factor, which is consistent with a role for Foxp3 in the regulatory phenotype of $\mathrm{CD} 4^{+} \mathrm{CD} 25^{+} \mathrm{T}$ cells in humans as well as mice (54). These findings show that human $\mathrm{CD} 4^{+} \mathrm{CD} 25^{+} \mathrm{T}$ cells can indeed suppress $\mathrm{T}$ cell activation by allergens and that this process may be deficient in atopic subjects.

In addition to $\mathrm{CD} 4^{+} \mathrm{CD} 25^{+} \mathrm{T}$ cells, IL-10-producing Tregs have been implicated in the prevention of atopic sensitization. Akdis et. al. showed an increased frequency of allergen-specific IL-10-producing $\mathrm{CD}^{+} \mathrm{T}$ cells in the blood of nonatopic individuals when compared to atopics and, furthermore, that these IL-10-producing T cells could specifically inhibit allergen-activated IL-4-producing T cells. Suppression was reversed by blocking antibodies to IL-10 and TGF- $\beta$ (55). The cells were isolated after allergen stimulation and were CD25+. How these cells relate to the $\mathrm{CD} 4^{+} \mathrm{CD} 25^{+} \mathrm{T}$ cells studied by others remains unclear; it is of note that suppression by induced $\mathrm{CD}^{+} \mathrm{CD} 25^{+} \mathrm{T}$ cells (derived from coculture of CD25$\mathrm{T}$ cells with $\mathrm{CD} 4^{+} \mathrm{CD} 25^{+} \mathrm{T}$ cells in vitro) was dependent on IL-10, in contrast to $\mathrm{CD} 4{ }^{+} \mathrm{CD} 25^{+} \mathrm{T}$ cells freshly isolated from blood, in which suppression was not reversed by blocking antibodies to IL-10 or IL-10 receptor $(54,56)$.

\section{Development of allergic sensitization: suppression versus activation of Th2 responses}

The factors determining the balance between a suppressive or regulatory response to allergen and activation of a Th2 response either during maturation of the immune system or after allergen sensitization are uncertain. One hypothesis for the increasing prevalence of Th2-associated allergic disease, the hygiene hypothesis, is that Western lifestyles reduce contact with environmental microorganisms. Such microorganisms are thought to modify antigen-presenting cells (in part via toll-like receptors [TLRs]) so that they induce either immune deviation in favor of Th1 responses or the development of Treg responses to allergens. Susceptibility to such factors may explain genetic associations of atopic disease with polymorphisms such as those described for the LPS receptor CD14 and TLR2 (57-59). Different concentrations of LPS could favor either Th1 or Th2 responses, and activation of TLR4 via LPS overcame regulation by $\mathrm{CD} 4^{+} \mathrm{CD} 25^{+} \mathrm{T}$ cells (60-62). Route, dose, and timing of allergen exposure, in addition to coexposure to pathogens or environmental bacteria, are all probably important in allergic sensitization. However, it is of note that allergic sensitization can occur in adulthood, so it is not the prerogative of the developing immune system. Both prior inhaled allergen exposure and exposure to mycobacterial antigens were shown to suppress 
subsequent allergic sensitization in mice through mechanisms that include induction of IL-10-producing Tregs (46-48). Such mechanisms may explain the apparent protective effect of exposure to cats during early childhood on the later development of atopic sensitization to cat allergens. High-dose exposure to cat allergen has been associated with a dominant IL-10 response in peripheral blood mononuclear cells cultured with cat allergen and elevated serum concentrations of cat allergen-specific IgG4; this has been termed a "modified Th2" response (63). Whether this relates to the development of Tregs is at present unclear. In contrast, house dust mite exposure showed no such protective effect. It will clearly be of interest to determine whether this high-exposure tolerance is akin to high-dose tolerance in mouse models, which is dependent on IL-10-producing Tregs, and whether the normal nonatopic state results from low-dose chronic tolerance as described in mouse models dependent on surface TGF- $\beta^{+}$Tregs (44). Recent data suggest that both IL-10-producing $\mathrm{T}$ cells and $\mathrm{CD} 4^{+} \mathrm{CD} 25^{+} \mathrm{T}$ cells may contribute to the development of tolerance since children lose atopic sensitization to cows' milk allergens $(64,65)$.

Further understanding of the maturation of regulatory responses will be required if preventive vaccination strategies are to be developed for allergic disease. The data from animal models of allergic airway sensitization suggest that naturally occurring $\mathrm{CD} 4{ }^{+} \mathrm{CD} 25^{+} \mathrm{T}$ cells derived from the thymus may not be sufficient to prevent airway inflammation and that more than one type of Treg may be required.

\section{Influence of allergy treatment on Treg populations}

Corticosteroids. How might Tregs be induced by therapy to control or prevent allergic disease? Corticosteroids are widely used as topical or systemic anti-inflammatory treatment for allergic disease and inhibit $\mathrm{T}$ cell activation and Th2 cytokine expression both in vitro and in vivo. In addition, corticosteroids increase IL-10 production by $\mathrm{T}$ cells and macrophages. In vitro exposure of human $\mathrm{CD} 4^{+} \mathrm{CD} 25^{+} \mathrm{T}$ cells to corticosteroids have been shown to increase their suppressive capacity in subsequent allergen-stimulated cultures, in part through an increase in IL-10 production (66). In addition, corticosteroids with vitamin D3 could induce an IL-10-producing Treg phenotype in vitro in both mouse and human CD $4^{+}$ $\mathrm{T}$ cells, and these IL-10-producing Tregs inhibited experimental allergic encephalomyelitis (49) and suppressed human allergenspecific Th2 cells in vitro (Catherine Hawrylowicz, King's College, London, United Kingdom; personal communication). Whether such strategies can be modified for in vivo use in treating human allergic disease remains to be determined. Current clinical experience indicates that, although corticosteroids can control allergic inflammation effectively, symptoms recur if they are discontinued. The development and duration of regulatory memory is poorly understood, but current steroid regimens do not appear to alter underlying sensitization. In contrast, allergen immunotherapy modulates Th2 responses to allergen, and this effect can persist for at least 3-4 years following discontinuation of therapy (67).

Allergen immunotherapy. Allergen immunotherapy involves the subcutaneous injection of incrementally increasing doses of allergen in order to suppress symptoms on subsequent reexposure to that allergen (68). In patients with severe seasonal pollinosis, grass pollen vaccination is highly effective (67-70). In children, 3 years of house dust mite extract immunotherapy prevented the onset of new allergen sensitivities (71) and resulted in a 2- to 3-fold reduction in the risk of developing physician-diagnosed asthma (72).
Some $(73,74)$, but not all $(75)$ studies have described decreased peripheral blood $\mathrm{T}$ cell responsiveness to allergen and/or immune deviation in favor of Th1 responses $(76,77)$. In some early reports, evidence of the induction of regulatory responses, for example, increased expression of IL-10, was not sought. Increased proportions of $\mathrm{CD}^{+} \mathrm{CD} 25^{+}$cells were found in grass pollen-stimulated peripheral blood mononuclear cell cultures following immunotherapy (78); these could represent a Treg population which might act to suppress Th2 T cells. In support of this hypothesis, grass pollen stimulation of PBMCs led to increased IL-10 production, which was colocalized to $\mathrm{CD} 4^{+} \mathrm{CD} 25^{+} \mathrm{T}$ cells. These findings are consistent with previous observations in venom-sensitive patients, which also suggest a role for IL-10 in suppression of allergen-specific Th2 responses $(73,79)$. A report of immunotherapy in patients with house dust mite allergy demonstrated increased $\mathrm{IL}-10^{+} \mathrm{CD} 4^{+} \mathrm{CD} 25^{+}$cells in peripheral blood after 70 days of treatment compared with before therapy (80). Whether these $\mathrm{CD} 4{ }^{+} \mathrm{CD} 25^{+} \mathrm{T}$ cells arise from the expansion of naturally occurring $\mathrm{CD}^{+} \mathrm{CD} 25^{+} \mathrm{T}$ cells or are analogous to IL-10-dependent $\mathrm{CD} 4{ }^{+} \mathrm{CD} 25^{+} \mathrm{T}$ cells induced in vitro (56) remains to determined.

Effective suppression of allergen-responsive $\mathrm{T}$ cells in target organs (such as the lung) requires trafficking of Tregs. Studies of in vivo suppression in animal models of inflammatory bowel disease suggest a role for locally produced IL-10 or TGF- $\beta$ (17). Allergen immunotherapy treatment is associated with reduced local nasal tissue infiltration by eosinophils, basophils, and Th2 $\mathrm{T}$ cells after allergen challenge together with local increases in $\mathrm{T}$ cells producing IL- 2 and IFN- $\gamma$ (Th1 cells), as detected by in situ hybridization $(75,81-83)$. In the same nasal biopsies, obtained during the peak pollen season, there were increases in the number of IL- $10^{+}$and TGF- $\beta^{+}$cells, detectable at both mRNA and protein levels (84). These increases in IL-10 and TGF- $\beta$ were not detectable outside the pollen season, suggesting that local mucosal contact with allergen was necessary for these effects. Neither were these cells detectable in normal nonatopic subjects, which suggested that these IL-10 and TGF- $\beta$ responses were not a feature of the normal mucosal response to pollen nor due to a toxic or other effect of pollen per se, in the absence of allergic sensitization. Colocalization studies confirmed that $15-20 \%$ of these nasal IL-10and TGF- $\beta$-producing cells were T cells, raising the possibility of an immunotherapy-induced, local adaptive mucosal $\mathrm{T}$ regulatory response following natural allergen exposure. Clearly the development of specific markers for Tregs is an urgent requirement for their tissue localization or isolation. However, IL-10 and TGF- $\beta$ also colocalized to macrophages (40\%) and alternative sources, including B cells and dendritic cells. It is therefore possible that local increases in IL-10 and TGF- $\beta$ from these innate immune cells may also result from the observed local increases in IFN- $\gamma$. Whether due to an immunotherapy-induced, allergen-specific $\mathrm{T}$ regulatory response (for example, production of IL-10 and/or TGF- $\beta$ ) and/or Th1 immune deviation (Th2 to Th1 shift in cytokine expression patterns), the production of these inhibitory cytokines within the nasal mucosa has the potential to suppress local allergen-specific Th2 cell responses and redirect antibody class switching in favor of IgG4 (IL-10 isotype switch factor), IgG (IFN- $\gamma$ isotype switch factor), and IgA (TGF- $\beta$ isotype switch factor).

In agreement with previous studies, our observations showed 40- to 100 -fold increases in serum allergen-specific total IgG and IgG4 subclass antibodies and blunting of seasonal increases in IgE (84). It is possible that such antibody changes are important for 

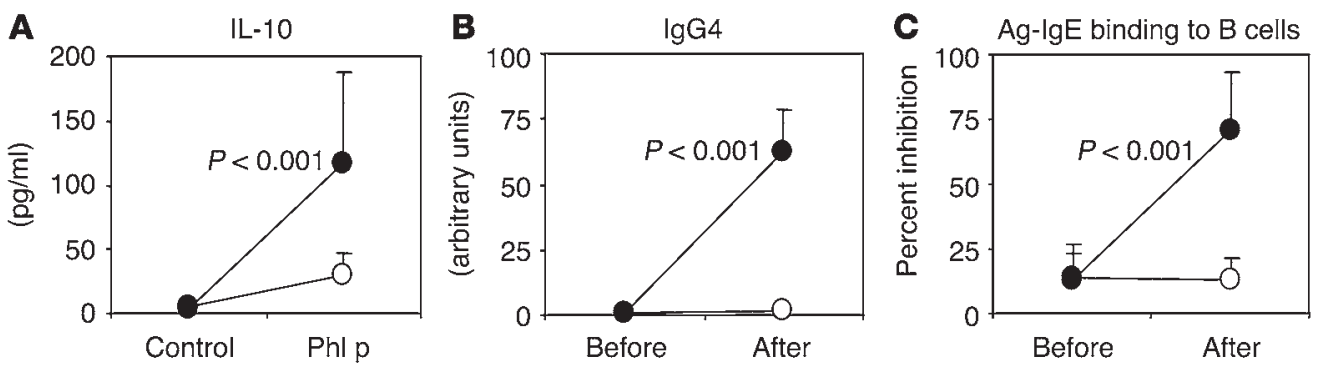

Figure 2

Immunological changes after allergen immunotherapy. Following 2-year grass pollen immunotherapy (closed circles), there were significant increases in (A) allergen-stimulated PBMC production of IL-10 (78); (B) serum concentrations of grass pollen (Phleum P5) allergen-specific IgG4 (84); and (C) serum inhibitory activity for allergen-IgE binding to B cells (88) compared with controls (open circles). These changes were accompanied by a reduction in symptoms and rescue medication use during the pollen season (83); inhibition of the allergen (grass pollen) induced late cutaneous response.

clinical efficacy of immunotherapy. For example, allergen-IgEIgG complexes may coaggregate inhibitory $\mathrm{Fc}-\gamma \mathrm{RIIb}$ receptors with high-affinity FceRI IgE receptors (85), resulting in the inhibition of FceRI signalling $(86,87)$. Alternatively, they may inhibit IgE-facilitated allergen presentation to $\mathrm{T}$ cells (88), a rate-limiting step in allergen-specific Th2 T cell-driven allergic responses (89). Increases in peripheral IL-10 production, serum allergen-specific IgG4, and IgG-dependent serum-inhibitory activity for allergenIgE binding to B cells after immunotherapy are shown in Figure 2. A hypothesis concerning the putative mechanism of allergen-injection immunotherapy is summarized in Figure 3.

\section{Modifications of allergen immunotherapy}

Despite the impressive efficacy of allergen-injection immunotherapy with whole allergen extracts, its widespread usage is confined to specialist centers in view of the risk of occasional IgE-mediated adverse events, which include systemic anaphylaxis. A number of strategies aim to modify immunotherapy for allergic disease in order to separate allergenicity (IgE cross-linking) from immunogenicity (induction of protective, non-IgE immunity).

Approaches have included the generation of allergoids through disruption of surface B cell epitopes of the protein. This has been achieved with amino-cross-linking agents such as glutaraldehyde

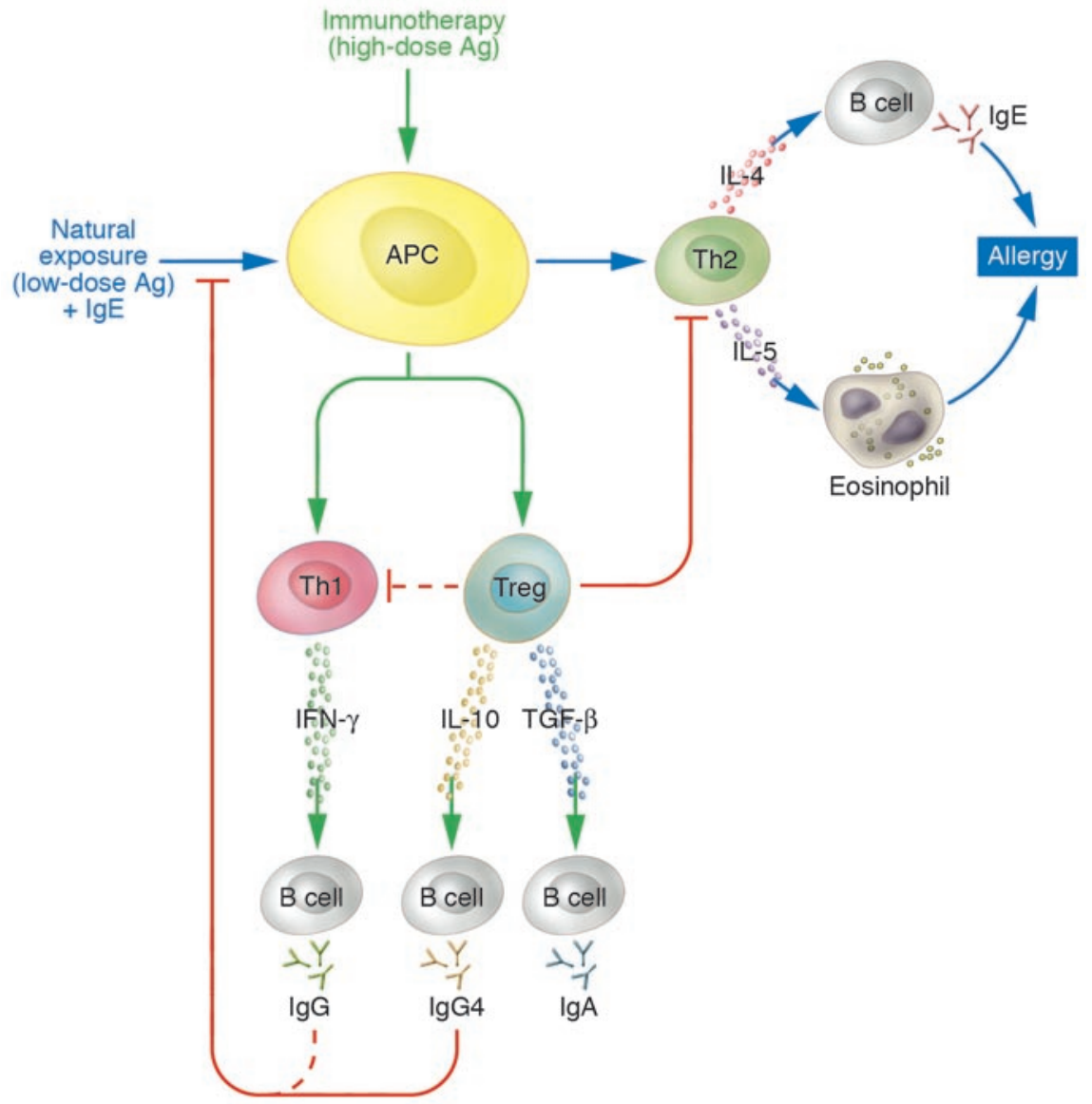

\section{Figure 3}

Potential mechanisms of conventional allergen immunotherapy. High-dose allergen exposure during immunotherapy results in both immune deviation of Th2 responses in favor of a Th0/Th1 response and in the generation of IL-10- and TGF- $\beta$-producing CD4 ${ }^{+}$CD $25^{+}$ $\mathrm{T}$ cells, possibly Tregs. IFN- $\gamma$-induced activation of bystander macrophages and/or other cells represents an alternative source of these inhibitory cytokines. During subsequent natural environmental exposure to allergens, the activation and/or maintenance of the usual atopic Th2 T cell response is inhibited. Additionally, these cytokines induce preferential switching of $B$ cell responses in favor of IgG and IgG4 antibodies (and possibly IgA antibodies under the influence of TGF- $\beta$ ). IgG may also inhibit IgE-facilitated allergen binding to antigen-presenting cells with subsequent downregulation of IgE-dependent Th2 T lymphocyte responses. Blue arrows represent immune response pathway to natural exposure (low-doses $\mathrm{Ag}$ and $\operatorname{lgE}$ ); green arrows represent immune response pathway to immunotherapy (highdose $\mathrm{Ag}$ ); red blocked lines represent inhibition (high-dose Ag); dotted lines represent possible means of action not yet proven. 

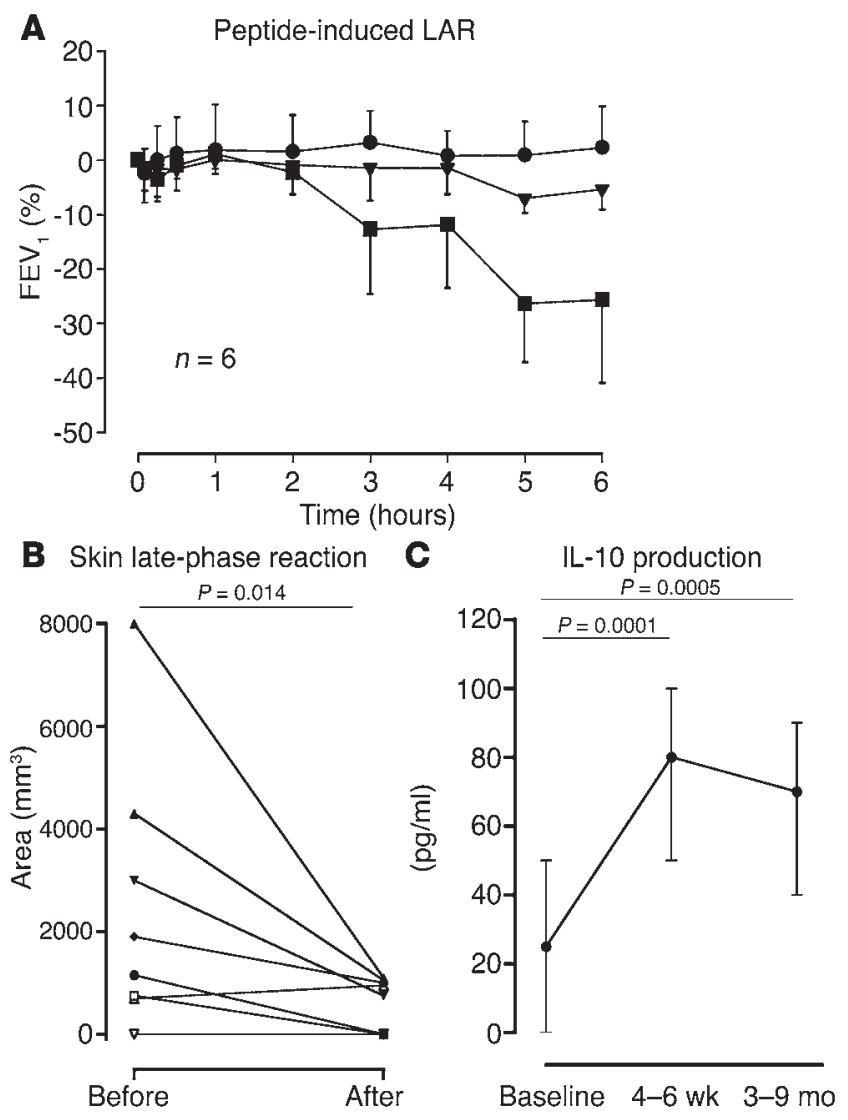

(or formalin). In general, allergoids have demonstrated efficacy and safety profiles similar to those described for unmodified allergen extracts (90). In other studies, the introduction of point mutations or deletions has been used to reduce the number of conformational B cell epitopes displayed by an allergen (91). More recently, allergen has been coupled to synthetic bacterial DNA sequences (92). In the case of DNA-allergen conjugates, the proposed mechanisms of action are 2-fold: steric hindrance of the interaction between allergen and IgE together with modulation of T cell responses toward a Th1 phenotype through activation of the TLR-9 molecule by bacterial DNA CpG motifs (93). Clinical studies evaluating the safety and efficacy of genetically engineered allergens (trimers and fragments of the major birch pollen allergen Bet v 1) and allergen-DNA conjugates (for example, immunostimulatory sequence-conjugated ragweed allergen) have thus far only been reported in abstract form.

During the last decade, synthetic peptides derived from the amino acid sequences of allergens have been evaluated for the treatment of allergic individuals. The majority of data has been obtained from the use of peptides derived from the major cat allergen Fel d 1, although more recently, studies have been performed with peptides from the bee venom allergen phospholipase $\mathrm{A}_{2}\left(\mathrm{PLA}_{2}\right)$. The potential of peptide immunotherapy to reduce IgEmediated allergenicity while maintaining immunogenicity has been examined in a number of clinical studies in recent years.

\section{Peptide immunotherapy}

Peptide therapy has been used in several animal models of human disease in an attempt to modulate $\mathrm{T}$ cell responses (94-99). Peptides from a variety of antigens have been administered intra-

\section{Figure 4}

Peptide immunotherapy is associated with allergen-specific hyporesponsiveness and the induction of IL-10. (A) Cat-allergic asthmatic subjects $(n=6)$ were challenged intradermally with a mixture of 12 peptides ( $5 \mu \mathrm{g}$ each) from the sequence of Fel $d 1$ or vehicle alone. Lung function was measured by spirometry for 6 hours. Challenges were separated by 14 days or more. Challenge with vehicle (circles) did not significantly modify forced expiratory volume in one second $\left(\mathrm{FEV}_{1}\right)$. Initial peptide challenge (squares) resulted in an isolated LAR that significantly differed from baseline ( $P=0.02$ area under the curve; AUC). A second challenge (triangles) with the same dose of peptide was associated with an attenuated or absent LAR. Values are mean of 6 individuals with standard error. (B) Cat-allergic asthmatic subjects underwent intradermal allergen challenge (volar aspect of the forearm) before and after administration of a mixture of 11 peptides in incremental divided doses. Peptide treatment significantly reduced the magnitude of the cutaneous late-phase reaction. (C) Treatment of 16 cat-allergic asthmatic individuals with a mixture of 12 peptides (incremental divided doses) resulted in elevated production of IL-10 by peripheral blood mononuclear cells at both 4-6 weeks and 3-9 months after the completion of treatment. Data presented as median and interquartile range.

nasally, orally, or by injection, leading to reduced proinflammatory responses accompanied by the induction of immunoregulatory cytokines such as IL-10 and/or TGF- $\beta$. Evidence for the functional existence of Tregs has been obtained in some murine models. For example, intramolecular suppression was demonstrated following intranasal administration of house dust mite peptides (100). Amelioration of disease was achieved following adoptive transfer of cells (101). Recently, oral administration of peptides to subjects with rheumatoid arthritis (phase I, open study) was associated with reductions in the PBMC production of IL-2, IFN- $\gamma$, and TNF- $\alpha$ as well as an increase in the production of IL-10, and an increase in the expression of mRNA encoding Foxp3 (102).

Short peptides (16/17 residues) representing $\mathrm{T}$ cell epitopes of the major cat allergen Fel d 1 did not trigger basophil histamine release or early asthmatic reactions upon intradermal injection or inhaled challenge in cat allergic asthmatic subjects (103-106). However, intradermal injection of allergen peptides did, in some individuals, lead to the induction of isolated late asthmatic reactions (LARs), which were MHC class II-restricted (103). Subsequent injection of peptides did not reproduce the response, implying the induction of tolerance (Figure 4). Development of peptide therapy based on these observations has enabled the safe delivery of molar doses of peptides far in excess of those possible with intact allergen molecules $(103,105)$.

The mechanism of abrogation of LAR and reduction of latephase skin reactions to allergen challenge was investigated by analysis of in vitro responses of PBMCs to allergen before and after peptide therapy (106). Supernatants harvested from cultures of PBMCs of cat-allergic subjects receiving Fel d 1 peptides or bee venom-allergic subjects receiving $\mathrm{PLA}_{2}$ peptides showed reductions in proliferation of $\mathrm{CD}^{+} \mathrm{T}$ cells and both Th1 and Th2 cytokine production, with a significant increase in IL-10 production. Similar results were reported by Müller and colleagues following $\mathrm{PLA}_{2}$ peptide therapy (107).

Preliminary data from clinical studies with Fel $\mathrm{d} 1$ peptides supports a central role for Tregs in the downregulation of allergic responses. An antigen-specific regulatory activity was present within the $\mathrm{CD}^{+}$peripheral $\mathrm{T}$ cell population after Fel $\mathrm{d} 1$ peptide therapy (108). Comparison of peripheral blood $\mathrm{CD} 4^{+} \mathrm{CD} 25^{+} \mathrm{T}$ 
cell suppression of cat allergen-stimulated CD4 ${ }^{+} \mathrm{CD} 25^{-} \mathrm{T}$ cells before and after peptide immunotherapy did not show any change in the suppressive ability of the $\mathrm{CD} 4^{+} \mathrm{CD} 25^{+} \mathrm{T}$ cell subset despite significant reduction of $\mathrm{CD}^{+} \mathrm{T}$ cell responses to allergen in this double-blind study (109). Thus peptide therapy may induce a regulatory subset separate from $\mathrm{CD} 4^{+} \mathrm{CD} 25^{+} \mathrm{T}$ cells, in other words, an adaptive rather than a naturally occurring regulatory population. However, analysis of 24-hour biopsy samples taken from allergen-induced cutaneous late-phase reactions to whole cat dander allergen extract showed increases in the number of $\mathrm{CD} 4^{+} \mathrm{CD} 25^{+}$cells, increases in the number of CD $4+\mathrm{IFN}-\gamma^{+}$ cells, and increases in TGF- $\beta$ expression following peptide therapy (110). Thus evidence for both immune deviation (increased IFN- $\gamma$ expression) and an indication of regulation (TGF- $\beta$ ) were found in this study.

\section{Conclusion}

In summary, current evidence suggests that human $\mathrm{CD} 4^{+} \mathrm{CD} 25^{+}$ $\mathrm{T}$ cells and IL-10-producing Tregs have the capacity to suppress Th2 responses to allergen and that this process may be defective in those who develop allergic sensitization. Allergen immunotherapy modifies $\mathrm{T}$ cell responses to allergen and may do so through induction of IL-10-producing Tregs, although other mechanisms, including Th1 immune deviation, are probably involved. Controversy remains about the nature and interrelation of different Treg populations; it is likely that $\mathrm{CD} 4^{+} \mathrm{CD} 25^{+} \mathrm{T}$ cells isolated from human adult blood represent a mixed population of naturally occurring Tregs analogous to those studied in mice and adaptive Tregs induced by low- or high-dose allergen exposure. The exact mechanism of suppression also remains controversial and may differ for different regulatory populations. Further work is required to determine the phenotype and derivation of such cells and to determine whether modification of existing immunotherapy can make such treatment more widely applicable and more effective. Greater understanding of regulatory mechanisms in the development of allergic sensitization and their manipulation by immunotherapy holds the promise of vaccination strategies to prevent allergic disease.

\section{Acknowledgments}

This work was funded in part by grants from the Medical Research Council, the Wellcome Trust, United Kingdom, and Asthma UK. D.S. Robinson is funded in part by a Research Leave Grant for Clinical Academics from the Wellcome Trust, United Kingdom, and M. Larché is an Asthma UK Senior Research Fellow. The authors are grateful to A.B. Kay, T. Williams, and members of the Departments of Allergy and Clinical Immunology, Upper Respiratory Medicine, and Leukocyte Biology, Imperial College London.

Address correspondence to: Stephen R. Durham, Department of Allergy and Clinical Immunology, National Heart and Lung Institute, Faculty of Medicine, Imperial College London, Dovehouse Street, London SW3 6LY, United Kingdom. Phone: 44-2073518992; Fax: 44-207-3518949; E-mail: s.durham@imperial.ac.uk.
1. Kay, A.B. 2001. Allergy and allergic diseases. N. Engl. J. Med. 344:30-37.

2. Lloyd, C.M., Gonzalo, J.A., Coyle, A.J., and Gutierrez-Ramos, J.C. 2001. Mouse models of allergic airway disease. Adv. Immunol. 77:263-295.

3. Robinson, D.S. 2000. Th-2 cytokines in allergic disease. Br. Med. Bull. 56:956-968.

4. Baecher-Allan, C., and Hafler, D.A. 2004. Suppressor T cells in human diseases. J. Exp. Med. 200:273-276.

5. Sakaguchi, S., Sakaguchi, N., Asano, M., Itoh, M., and Toda, M. 1995. Immunologic self-tolerance maintained by activated T cells expressing IL-2 receptor alpha-chains (CD25). Breakdown of a single mechanism of self-tolerance causes various autoimmune diseases. J. Immunol. 155:1151-1164.

6. Sakaguchi, S. 2000. Regulatory T cells: key controllers of immunologic self-tolerance. Cell. 101:455-458.

7. Shevach, E.M. 2002. CD4+ CD25+ suppressor T cells: more questions than answers. Nat. Rev. Immunol. 2:389-400.

8. Levings, M.K., Sangregorio, R., and Roncarolo, M.-G. 2001. Human $\mathrm{CD} 25^{+} \mathrm{CD} 4^{+} \mathrm{T}$ regulatory cells suppress naive and memory $\mathrm{T}$ cell proliferation and can be expanded in vitro without loss of function. J. Exp. Med. 193:1295-1302.

9. Jonuleit, H., et al. 2001. Identification and functional characterization of human $\mathrm{CD} 4^{+} \mathrm{CD} 25^{+}$ $\mathrm{T}$ cells with regulatory properties isolated from peripheral blood. J. Exp. Med. 193:1285-1294.

10. Dieckmann, D., Plottner, H., Berchtold, S., Berger, S., and Schuler, G. 2001. Ex vivo isolation and characterization of $\mathrm{CD} 4{ }^{+} \mathrm{CD} 25^{+} \mathrm{T}$ cells with regulatory properties from human blood. J. Exp. Med. 193:1303-1310.

11. Taams, L.S., et al. 2001. Human anergic/suppressive CD4(+)CD25(+) T cells: a highly differentiated and apoptosis-prone population. Eur. J. Immunol. 31:1122-1131.

12. Ng, W.F., et al. 2001. Human CD4(+)CD25(+) cells: a naturally occurring population of regulatory $\mathrm{T}$ cells. Blood. 98:2736-2744.

13. Stephens, L.A., Mottet, C., Mason, D., and Powrie, F. 2001. Human CD4(+)CD25(+) thymocytes and peripheral $\mathrm{T}$ cells have immune suppressive activity in vitro. Eur. J. Immunol. 31:1247-1254.

14. Bluestone, J.A., and Abbas, A.K. 2003. Natural versus adaptive regulatory T cells. Nat. Rev. Immunol. 3:253-257.

15. Stephens, L.A., and Mason, D. 2000. CD25 is a marker for CD4+ thymocytes that prevent autoimmune diabetes in rats, but peripheral $T$ cells with this function are found in both CD25+ and CD25subpopulations. J. Immunol. 165:3105-3110.

16. Chen, Y., Kuchroo, V.K., Inobe, J., Hafler, D.A., and Weiner, H.L. 1994. Regulatory T cell clones induced by oral tolerance: suppression of autoimmune encephalomyelitis. Science. 265:1237-1240.

17. Maloy, K.J., and Powrie, F. 2001. Regulatory T cells in the control of immune pathology. Nat. Immunol. 2:816-822.

18. Baecher-Allan, C., Brown, J.A., Freeman, G.J., and Hafler, D.A. 2001. CD4+CD25high regulatory cells in human peripheral blood. J. Immunol. 167:1245-1253.

19. Takahashi, T., et al. 2000. Immunologic self-tolerance maintained by $\mathrm{CD} 25(+) \mathrm{CD} 4(+)$ regulatory $\mathrm{T}$ cells constitutively expressing cytotoxic T lymphocyte-associated antigen 4. J. Exp. Med. 192:303-310.

20. Read, S., Malmstrom, V., and Powrie, F. 2000. Cytotoxic T lymphocyte-associated antigen 4 plays an essential role in the function of CD25(+)CD4(+) regulatory cells that control intestinal inflammation. J. Exp. Med. 192:295-302.

21. Nakamura, K., Kitani, A., and Strober, W. 2001. Cell contact-dependent immunosuppression by $\mathrm{CD} 4(+) \mathrm{CD} 25(+)$ regulatory $\mathrm{T}$ cells is mediated by cell surface-bound transforming growth factor beta. J. Exp. Med. 194:629-644.

22. Shimizu, J., Yamazaki, S., Takahashi, T., Ishida, Y., and Sakaguchi, S. 2002. Stimulation of $\mathrm{CD} 25(+) \mathrm{CD} 4(+)$ regulatory $\mathrm{T}$ cells through GITR breaks immunological self-tolerance. Nat. Immunol. 3:135-142.

23. McHugh, R.S., et al. 2002. CD4(+)CD25(+) immunoregulatory $\mathrm{T}$ cells: gene expression analysis reveals a functional role for the glucocorticoidinduced TNF receptor. Immunity. 16:311-323.

24. Piccirillo, C.A., et al. 2002. CD4(+)CD25(+) regulatory $\mathrm{T}$ cells can mediate suppressor function in the absence of transforming growth factor beta1 production and responsiveness. J. Exp. Med. 196:237-246.

25. Thornton, A.M., and Shevach, E.M. 1998. CD4+CD25+ immunoregulatory $\mathrm{T}$ cells suppress polyclonal $\mathrm{T}$ cell activation in vitro by inhibiting interleukin 2 production. J. Exp. Med. 188:287-296.

26. Hori, S., Nomura, T., and Sakaguchi, S. 2003. Control of regulatory $\mathrm{T}$ cell development by the transcription factor Foxp3. Science. 299:1057-1061.

27. Fontenot, J.D., Gavin, M.A., and Rudensky, A.Y. 2003. Foxp3 programs the development and function of CD4+CD25+ regulatory T cells. Nat. Immunol. 4:330-336.

28. Khattri, R., Cox, T., Yasayko, S.A., and Ramsdell, F. 2003. An essential role for Scurfin in CD4+CD25+ T regulatory cells. Nat. Immunol. 4:337-342.

29. Chen, W., et al. 2003. Conversion of peripheral CD4+CD25- naive $\mathrm{T}$ cells to $\mathrm{CD} 4+\mathrm{CD} 25+$ regulatory $\mathrm{T}$ cells by TGF-beta induction of transcription factor Foxp3. J. Exp. Med. 198:1875-1886.

30. Wildin, R.S., et al. 2001. X-linked neonatal diabetes mellitus, enteropathy and endocrinopathy syndrome is the human equivalent of mouse scurfy. Nat. Genet. 27:18-20.

31. O'Garra, A., and Vieira, P. 2003. Twenty-first century Foxp3. Nat. Immunol. 4:304-306.

32. Vieira, P.L., et al. 2004. IL-10-secreting regulatory $\mathrm{T}$ cells do not express Foxp3 but have comparable regulatory function to naturally occurring CD4+CD25+ regulatory T cells. J. Immunol. 172:5986-5993.

33. Cohn, L., Homer, R.J., Niu, N., and Bottomly, K. 1999. Thelper 1 cells and interferon gamma regulate 
allergic airway inflammation and mucus production. J. Exp. Med. 190:1309-1318.

34. Szabo, S.J., et al. 2002. Distinct effects of T-bet in TH1 lineage commitment and IFN-gamma production in CD4 and CD8 T cells. Science. 295:338-342.

35. Finotto S., et al. 2002. Development of spontaneous airway changes consistent with human asthma in mice lacking T-bet. Science. 295:336-338.

36. Umetsu, D.T., Akbari, O., and Dekruyff, R.H. 2003. Regulatory T cells control the development of allergic disease and asthma. J. Allergy Clin. Immunol. 112:480-487.

37. Stassen, M., et al. 2004. Differential regulatory capacity of $\mathrm{CD} 25+\mathrm{T}$ regulatory cells and preactivated $\mathrm{CD} 25+\mathrm{T}$ regulatory cells on development, functional activation, and proliferation of Th2 cells. J. Immunol. 173:267-274.

38. Curotto de Lafaille, M.A., et al. 2001. Hyper immunoglobulin $\mathrm{E}$ response in mice with monoclonal populations of B and T lymphocytes. J. Exp. Med. 194:1349-1359.

39. Suto, A., et al. 2001. Role of CD4(+) CD25(+) regulatory $\mathrm{T}$ cells in $\mathrm{T}$ helper 2 cell-mediated allergic inflammation in the airways. Am. J. Respir. Crit. Care Med. 164:680-687.

40. Jaffar, Z., Sivakuru, T., and Roberts, K. 2004. $\mathrm{CD} 4+\mathrm{CD} 25+\mathrm{T}$ cells regulate airway eosinophilic inflammation by modulating the Th2 cell phenotype. J. Immunol. 172:3842-3849.

41. Hadeiba, H., and Locksley, R.M. 2003. Lung CD25 CD4 regulatory T cells suppress type 2 immune responses but not bronchial hyperreactivity. J. Immunol. 170:5502-5510.

42. McMenamin, C., Pimm, C., McKersey, M., and Holt, P.G. 1994. Regulation of IgE responses to inhaled antigen in mice by antigen-specific gamma delta $\mathrm{T}$ cells. Science. 265:1869-1871.

43. Hurst, S.D., Seymour, B.W., Muchamuel, T., Kurup, V.P., and Coffman, R.L. 2001. Modulation of inhaled antigen-induced IgE tolerance by ongoing Th2 responses in the lung. J. Immunol. 166:4922-4930.

44. Ostroukhova, M., et al. 2004. Tolerance induced by inhaled antigen involves $\mathrm{CD} 4^{+} \mathrm{T}$ cells expressing membrane-bound TGF- $\beta$ and FOXP3. J. Clin. Invest. 114:28-38. doi:10.1172/JCI200420509.

45. Cottrez, F., Hurst, S.D., Coffman, R.L., and Groux, H. 2000. T regulatory cells 1 inhibit a Th2-specific response in vivo. J. Immunol. 165:4848-4853.

46. Akbari, O., et al. 2002. Antigen-specific regulatory $\mathrm{T}$ cells develop via the ICOS-ICOS-ligand pathway and inhibit allergen-induced airway hyperreactivity. Nat. Med. 8:1024-1032.

47. Akbari, O., DeKruyff, R.H., and Umetsu, D.T. 2001. Pulmonary dendritic cells producing IL-10 mediate tolerance induced by respiratory exposure to antigen. Nat. Immunol. 2:725-731.

48. Zuany-Amorim, C., et al. 2002. Suppression of airway eosinophilia by killed Mycobacterium vaccaeinduced allergen-specific regulatory T-cells. Nat. Med. 8:625-629.

49. Barrat, F.J., et al. 2002. In vitro generation of interleukin 10-producing regulatory CD4(+) T cells is induced by immunosuppressive drugs and inhibited by Thelper type 1 (Th1)- and Th2-inducing cytokines. J. Exp. Med. 195:603-616.

50. Hoyne, G.F., Dallman, M.J., Champion, B.R., and Lamb, J.R. 2001. Notch signalling in the regulation of peripheral immunity. Immunol. Rev 182:215-227.

51. Cosmi, L., et al. 2004. Th2 cells are less susceptible than Th1 cells to the suppressive activity of CD25+ regulatory thymocytes because of their responsiveness to different cytokines. Blood. 103:3117-3121.

52. Tiemessen, M.M., et al. 2002. CD4 CD25 regulatory $\mathrm{T}$ cells are not functionally impaired in adult patients with IgE-mediated cow's milk allergy.
J. Allergy Clin. Immunol. 110:934-936.

53. Bellinghausen, I., Klostermann, B., Knop, J., and Saloga, J. 2003. Human CD4+CD25+ T cells derived from the majority of atopic donors are able to suppress TH1 and TH2 cytokine production. J. Allergy Clin. Immunol. 111:862-868.

54. Ling, E.M., et al. 2004. Relation of CD4+CD25+ regulatory T-cell suppression of allergen-driven T-cell activation to atopic status and expression of allergic disease. Lancet. 363:608-615.

55. Akdis, M., et al. 2004. Immune responses in healthy and allergic individuals are characterized by a fine balance between allergen-specific $T$ regulatory 1 and T helper 2 cells. J. Exp. Med. 199:1567-1575.

56. Dieckmann, D., Bruett, C.H., Ploettner, H., Lutz, M.B., and Schuler, G. 2002. Human CD4(+)CD25(+) regulatory, contact-dependent $\mathrm{T}$ cells induce interleukin 10-producing, contactindependent type 1-like regulatory T cells. J. Exp. Med. 196:247-253.

57. Umetsu, D.T., McIntire, J.J., Akbari, O., Macaubas, C., and DeKruyff, R.H. 2002. Asthma: an epidemic of dysregulated immunity. Nat. Immunol. 3:715-720.

58. Baldini, M., et al. 1999. A polymorphism* in the 5 ' flanking region of the CD14 gene is associated with circulating soluble CD14 levels and with total serum immunoglobulin E. Am. J. Respir. Cell Mol. Biol. 20:976-983.

59. Eder, W., et al. 2004. Toll-like receptor 2 as a major gene for asthma in children of European farmers. J. Allergy. Clin. Immunol. 113:482-488.

60. Eisenbarth, S.C., et al. 2002. Lipopolysaccharideenhanced, toll-like receptor 4-dependent $\mathrm{T}$ helper cell type 2 responses to inhaled antigen. J. Exp. Med. 196:1645-1651.

61. Pasare, C., and Medzhitov, R. 2003. Toll-like receptors: balancing host resistance with immune tolerance. Curr. Opin. Immunol. 15:677-682.

62. Pasare, C., and Medzhitov, R. 2003. Toll pathway-dependent blockade of CD4+CD25+ T cellmediated suppression by dendritic cells. Science. 299:1033-1036.

63. Platts-Mills, T., Vaughan, J., Squillace, S., Woodfolk, J., and Sporik, R. 2001. Sensitisation, asthma, and a modified Th2 response in children exposed to cat allergen: a population-based cross-sectional study. Lancet. 357:752-756.

64. Karlsson, M.R., Rugtveit, J., and Brandtzaeg, P. 2004. Allergen-responsive CD4+CD25+ regulatory $\mathrm{T}$ cells in children who have outgrown cow's milk allergy. J. Exp. Med. 199:1679-1688.

65. Tiemessen, M.M., et al. 2004. Cow's milk-specific Tcell reactivity of children with and without persistent cow's milk allergy: key role for IL-10. J. Allergy Clin. Immunol. 113:932-939.

66. Robinson, D.S., and Nguyen, X.D. 2004. Fluticasone propionate increases suppression of allergendriven $\mathrm{T}$ cell proliferation by CD4+CD25+ T cells. J. Allergy Clin. Immunol. 114:296-301.

67. Durham, S.R., et al. 1999. Long-term clinical efficacy of grass-pollen immunotherapy. N. Engl. J. Med. 341:468-475.

68. Till, S.J., and Durham, S.R. 2004. Immunological responses to allergen immunotherapy. Clin. Allergy Immunol. 18:85-104.

69. Varney, V.A., et al. 1991. Usefulness of immunotherapy in patients with severe summer hay fever uncontrolled by antiallergic drugs. BMJ. 302:265-269.

70. Bousquet, J., et al. 1998. Allergen immunotherapy: therapeutic vaccines for allergic diseases. World Health Organization. American Academy of Allergy, Asthma and Immunology. Ann. Allergy Asthma Immunol. 81:401-405.

71. Pajno, G.B., Barberio, G., De Luca, F., Morabito, L., and Parmiani, S. 2001. Prevention of new sensitizations in asthmatic children monosensitized to house dust mite by specific immunotherapy. A six-year follow-up study. Clin. Exp. Allergy. 31:1392-1397.

72. Moller, C., et al. 2002. Pollen immunotherapy reduces the development of asthma in children with seasonal rhinoconjunctivitis (the PAT-study). J. Allergy Clin. Immunol. 109:251-256.

73. Akdis, M., et al. 1996. Epitope-specific T-cell tolerance to phospholipase $\mathrm{A}_{2}$ in bee venom immunotherapy and recovery by IL-2 and IL-15 in vitro. J. Clin. Invest. 98:1676-1683.

74. Till, S., et al. 1997. IL-5 production by allergen-stimulated T-cells following grass pollen immunotherapy for seasonal allergic rhinitis. Clin. Exp. Immunol. 110:114-121.

75. Wachholz, P., et al. 2002. Grass pollen immunotherapy for hayfever is associated with increases in local nasal mucosal but not peripheral Th1/Th2 ratios. Immunology. 105:56-62.

76. Ebner, C., et al. 1997. Immunological changes during specific immunotherapy of grass pollen allergy: reduced lymphoproliferative responses to allergen and shift from TH2 to TH1 in T-cell clones specific for Phl p 1, a major grass pollen allergen. Clin. Exp. Allergy. 27:1007-1015.

77. Jutel, M., et al. 1995. Bee venom immunotherapy results in decrease of IL-4 and IL-5 and increase of IFN-gamma secretion in specific allergen-stimulated T-cell cultures. J. Immunol. 154:4187-4194.

78. Francis, J.N., Till, S.J., and Durham, S.R. 2003. Induction of IL-10+CD4+CD25+ T cells by grass pollen immunotherapy. J. Allergy Clin. Immunol. 111:1255-1261.

79. Bellinghausen, I., et al. 1997. Insect venom immunotherapy induces interleukin-10 production and a Th2- to-Th1 shift, and changes surface marker expression in venom-allergic subjects. Eur. J. Immunol. 27:1131-1139.

80. Jutel, M., et al. 2003. IL-10 and TGF-beta cooperate in the regulatory $\mathrm{T}$ cell response to mucosal allergens in normal immunity and specific immunotherapy. Eur. J. Immunol. 33:1205-1214.

81. Varney, V.A., et al. 1993. Influence of grass pollen immunotherapy on cellular infiltration and cytokine mRNA expression during allergeninduced late-phase cutaneous responses. J. Clin. Invest. 92:644-651.

82. Durham, S.R., et al. 1996. Grass pollen immunotherapy inhibits allergen-induced infiltration of CD4+ $\mathrm{T}$ lymphocytes and eosinophils in the nasal mucosa and increases the number of cells expressing messenger RNA for interferon-gamma. J. Allergy Clin. Immunol. 97:1356-1365.

83. Wilson, D.R., et al. 2001. Grass pollen immunotherapy inhibits seasonal increases in basophils and eosinophils in the nasal epithelium. Clin. Exp. Allergy. 31:1705-1713.

84. Nouri-Aria, K., et al. 2004. Grass pollen immunotherapy induces mucosal and peripheral IL-10 responses and blocking IgG activity. J. Immunol. 172:3252-3259.

85. Daeron, M., et al. 1995. The same tyrosine-based inhibition motif, in the intracytoplasmic domain of Fc gamma RIIB, regulates negatively BCR-, TCR-, and FcR-dependent cell activation. Immunity. 3:635-646.

86. Malbec, O., et al. 1998. Fc epsilon receptor I-associated lyn-dependent phosphorylation of Fc gamma receptor IIB during negative regulation of mast cell activation. J. Immunol. 160:1647-1658.

87. Zhu, D., Kepley, C.L., Zhang, M., Zhang, K., and Saxon, A. 2002. A novel human immunoglobulin Fc gamma Fc epsilon bifunctional fusion protein inhibits Fc epsilon RI-mediated degranulation. Nat. Med. 8:518-521.

88. Wachholz, P.A., Soni, N.K., Till, S.J., and Durham, S.R. 2003. Inhibition of allergen-IgE binding to B cells by IgG antibodies after grass pollen immunotherapy. 
J. Allergy Clin. Immunol. 112:915-922.

89. Van Neerven, R.J., et al. 1999. Blocking antibodies induced by specific allergy vaccination prevent the activation of $\mathrm{CD} 4+\mathrm{T}$ cells by inhibiting serumIgE-facilitated allergen presentation. J. Immunol. 163:2944-2952.

90. Norman, P.S., Lichtenstein, L.M., and Marsh, D.G. 1981. Studies on allergoids from naturally occurring allergens. IV. Efficacy and safety of long-term allergoid treatment of ragweed hay fever. J. Allergy Clin. Immunol. 68:460-470.

91. Pauli, G., et al. 2000. Comparison of genetically engineered hypoallergenic rBet $\mathrm{v} 1$ derivatives with rBet $\mathrm{v} 1$ wild-type by skin prick and intradermal testing: results obtained in a French population. Clin. Exp. Allergy. 30:1076-1084.

92. Tighe, H., et al. 2000. Conjugation of immunostimulatory DNA to the short ragweed allergen amb a 1 enhances its immunogenicity and reduces its allergenicity. J. Allergy Clin. Immunol. 106:124-134.

93. Rachmilewitz, D., et al. 2004. Toll-like receptor 9 signaling mediates the anti-inflammatory effects of probiotics in murine experimental colitis. Gastroenterology. 126:520-528.

94. Gaur, A., Wiers, B., Liu, A., Rothbard, J., and Fathman, C.G. 1992. Amelioration of autoimmune encephalomyelitis by myelin basic protein synthetic peptide-induced anergy. Science. 258:1491-1494.

95. Clayton, J.P., et al. 1989. Peptide-specific prevention of experimental allergic encephalomyelitis. Neonatal tolerance induced to the dominant $T$ cell determinant of myelin basic protein. J. Exp. Med. 169:1681-1691.

96. Daniel, D., and Wegmann, D.R. 1996. Protection of non-obese diabetic mice from diabetes by intranasal or subcutaneous administration of insulin peptide B-(9-23). Proc. Natl. Acad. Sci. U. S. A. 93:956-960.

97. Metzler, B., and Wraith, D.C. 1993. Inhibition of experimental autoimmune encephalomyelitis by inhalation but not oral administration of the encephalitogenic peptide: influence of MHC binding affinity. Int. Immunol. 5:1159-1165.

98. Burkhart, C., Liu, G.Y., Anderton, S.M., Metzler, B., and Wraith, D.C. 1999. Peptide-induced T cell regulation of experimental autoimmune encephalomyelitis: a role for IL-10. Int. Immunol. 11:1625-1634.

99. Prakken, B.J., et al. 1997. Peptide-induced nasal tolerance for a mycobacterial heat shock protein $60 \mathrm{~T}$ cell epitope in rats suppresses both adjuvant arthritis and nonmicrobially induced experimental arthritis. Proc. Natl. Acad. Sci. U. S. A. 94:3284-3289.

100.Hoyne, G.F., O'Hehir, R.E., Wraith, D.C., Thomas, W.R., and Lamb, J.R. 1993. Inhibition of T cell and antibody responses to house dust mite allergen by inhalation of the dominant $\mathrm{T}$ cell epitope in naive and sensitized mice. J. Exp. Med. 178:1783-1788.

101.Sundstedt, A., O'Neill, E.J., Nicolson, K.S., and Wraith, D.C. 2003. Role for IL-10 in suppression mediated by peptide-induced regulatory $\mathrm{T}$ cells in vivo. J. Immunol. 170:1240-1248.

102.Prakken, B.J., et al. 2004. Epitope-specific immunotherapy induces immune deviation of proinflammatory $\mathrm{T}$ cells in rheumatoid arthritis. Proc. Natl. Acad. Sci. U. S. A. 101:4228-4233.

103.Haselden, B.M., Kay, A.B., and Larche, M. 1999. Immunoglobulin E-independent major histocompatibility complex-restricted $\mathrm{T}$ cell peptide epitope-induced late asthmatic reactions. J. Exp. Med. 189:1885-1894.
104.Ali, F.R., Oldfield, W.L., Higashi, N., Larche, M., and Kay, A.B. 2004. Late asthmatic reactions induced by inhalation of allergen-derived T cell peptides. Am.J. Respir. Crit. Care Med. 169:20-26.

105.Oldfield, W.L., Larche, M., and Kay, A.B. 2002. Effect of T-cell peptides derived from Fel $\mathrm{d} 1$ on allergic reactions and cytokine production in patients sensitive to cats: a randomised controlled trial. Lancet. 360:47-53.

106. Oldfield, W.L., Kay, A.B., and Larche, M. 2001. Allergen-derived $T$ cell peptide-induced late asthmatic reactions precede the induction of antigen-specific hyporesponsiveness in atopic allergic asthmatic subjects. J. Immunol. 167:1734-1739.

107. Muller, U., et al. 1998. Successful immunotherapy with T-cell epitope peptides of bee venom phospholipase A2 induces specific T-cell anergy in patients allergic to bee venom. J. Allergy Clin. Immunol. 101:747-754.

108.Verhoef, A., Alexander, C., Kay, A.B., and Larché, M. 2004. Allergen-based peptide immunotherapy is associated with functional modifications in allergen-specific T-cell subpopulations [abstract]. J. Allergy Clin. Immunol. 113(Suppl.):918.

109.Smith, T.R.F, Alexander, C., Kay, A.B., Larché, M., and Robinson, D.S. 2004. Cat allergen peptide immunotherapy reduces $\mathrm{CD} 4^{+} \mathrm{T}$ cell responses to cat allergen but does not alter suppression by CD4 ${ }^{+} \mathrm{CD} 25^{+}$T cells. Allergy. 59:1097-1101.

110.Alexander, C., Ying, S., Kay, A.B., and Larché, M. 2004. Fel d 1-derived T cell peptide therapy induces recruitment of activated $(\mathrm{CD} 4+\mathrm{CD} 25+; \mathrm{CD} 4+\mathrm{IFN}$ gamma+) Th1 cells to sites of allergen-induced late-phase skin reactions in cat-allergic subjects. Clin. Exp. Allergy. In press. 